\title{
A study on effect of performing quality management system on organizational productivity
}

\author{
M. M. Movahedi ${ }^{a^{*}}$, Minoo Teimourpour ${ }^{b}$ and Nahid Teimourpour
}

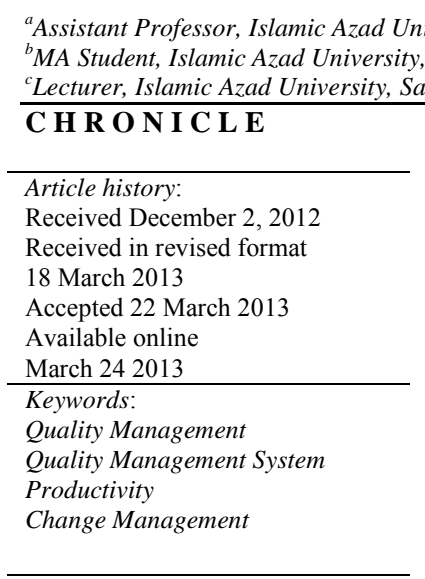

Article history:

Received December 2, 2012

revised format

Accepted 22 March 2013

Available online

Keywords:

Quality Management

Productivity

Change Management

University, Firoozkooh Branch, Industrial Management School, Firoozkooh, Iran

University, Firoozkooh Branch, Industrial Management School, Firoozkooh, Iran

${ }^{c}$ Lecturer, Islamic Azad University, Sama Branch, Iran

\section{A B S T R A C T}

\begin{abstract}
The main purpose of article is to survey the effect of Quality Management System (QMS) on organization efficiency based on the concept of change management. The role of top organization management for QMS implementation and change management solutions to eliminate organization resistance are investigated. In this study, fourteen Deming's principles are independent variables, organization productivity is dependent variable and the study examines six different hypotheses. Cronbach Alpha coefficient is calculated as $87.62 \%$, which validates research questionnaire. The proposed study of this paper uses t-student to examine all six hypotheses in a case study from a firm named Aria Sanaat factory. The results of this study confirm that there are some positive effects on organizational management variables \& establishing training and explanation courses \& meetings.
\end{abstract}

\section{Introduction}

Total Quality Management (TQM) and Quality Management Systems (QMS) are general and regular methodologies for management tendencies in quality debates and efficiency improvements. These two techniques have become some of the most popular solution strategies for productivity improvement. The purpose of this approach is to increase performances of business units in terms of quality, efficiency, customer's satisfaction and profitability (Sadikoglu \& Zehir, 2010). Quality cannot be separated from human's life and the literatures show quality is designable and thoughtful before business (Kemp, 2006) and shall be surveyed from customer's point of view. Quality consists of every physical or nonphysical component, which changes the product value in customer's perspectives.

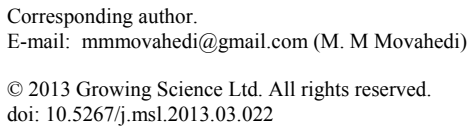


Development of competitive business environment, changing customer's choices, companies' activities peer-industries in different industries and services have created motivations among managers to pay especial attention on TQM. The outcome of this attendance is reach better quality, business performance improvement and competitiveness (Feng et al., 2006). The development of quality management systems helps for implementing quality standards. Although these standards are not able to describe the quality management system but they are required and are needed to formulate, to analyze and to improve processes. The standard of ISO900 family has been the most popular quality management system and many companies and organizations all around the world have used it. Quality management systems help companies understand the most qualified products and recovered processes and the complexity of these factors leads to gain customers satisfaction (Pfeifer, 2002).

Researchers have performed tremendous efforts around quality management systems in recent years. Zhang et al. (2012), for instance, investigated the moderating role of contextual factors on quality management practices and Kim et al. (2012) studied the relationship between quality management practices and innovation. According to Pfeifer et al. (2004), integrating six sigma with quality management systems sigma must be integrated with management systems concepts. He also recommended combining these two program challenges and their common features to get the maximum profit. Aggelogiannopoulos et al. (2007) studied the implementation of a QMS based on the ISO 9000 family in a Greek small-sized winery and discussed on how programming and implementing of quality management system could help improve productivity. He pointed that the top managers should follow to get the whole internal and external profit from emission of quality management system certificates and they must look for increasing the market share, forcing to new markets in gaining such profits.

Priede (2012) explained that quality management has a significant role in increasing the competiveness of companies and economic over the past 60 years. He reviewed the literature for quality management system and ISO9001 and concentrated on its strategic requirements. The author noticed to introduce the quality management as a significant part in economic completion by global competitiveness report. The strategic benefits and importance of quality management system has been studied through the company's observation and the implementation of quality management system has been verified in the world (Priede, 2012). Many researchers have verified that there is strong correlation between quality and productivity (Defeo \& Juran, 2010).

The present study tries to verify whether there is a relationship between the increase of productivity by performing the quality management systems and the existence of employees responds against the changes. The primary objective of the present study is to study the effects of QMS implementation on organization performance by considering the change management roles. Therefore, we first review the productivity and QMS literatures and present the proposed method and conceptual model. We also discuss the research hypotheses by debating the assumptions and by using the t-student statistics tests and discuss outstanding outcomes of the research.

\section{Literature Review}

\subsection{Productivity}

Productivity is an average measure of the efficiency of production and it is calculated as a ratio of production output to what is required to produce it (inputs of capital, labor, land, energy, materials, etc.). The measure of productivity can be expressed as a total output per one unit of a total input. There are different advantages on of reaching high productivity and productivity growth plays essential role because more income means that the firm can meet its expectations. In addition, the firm has been able to accomplish to meet customers' obligations, suppliers, workers, shareholders, 
and governments (taxes and regulation), and still remain competitive or even improve its competitiveness in the market place (Gollop, 1979; Kurosawa, 1975; Pineda, 1990; Saari, 2006). Productivity expresses as a relationship between the quantity of goods and services produced by a business or an economy and the quantity of labor, capital, energy, and other resources needed to produce the goods and services (Worrell et al., 2001). The results of the activities performed about productivity are stated in four perspectives, which include cost reduction, decrease process start up, increasing quantity and quality improvement. There are also five strategies to reach productivity stated in Table 1.

\section{Table 1}

Five productivity strategies

\begin{tabular}{ll}
\hline Strategy & \multicolumn{1}{c}{ Definition } \\
\hline Plan & It means a conscious act, a guide (or collection of them) to encounter a condition \\
Map & It means a kind of arrangement to overcome the rival \\
Pattern & A pattern of the actions that can be completely new or pre-defined \\
Position & The analysis of the position by which we view the issue (the position of the organization in external environment) \\
Perspective & Mental attitudes of the organization strategies (inside the organization) \\
\hline
\end{tabular}

All productivity strategies are based on organization strategic models, which were first stated by Edward Deming and Fig. 1 demonstrates details of the relationships among them.

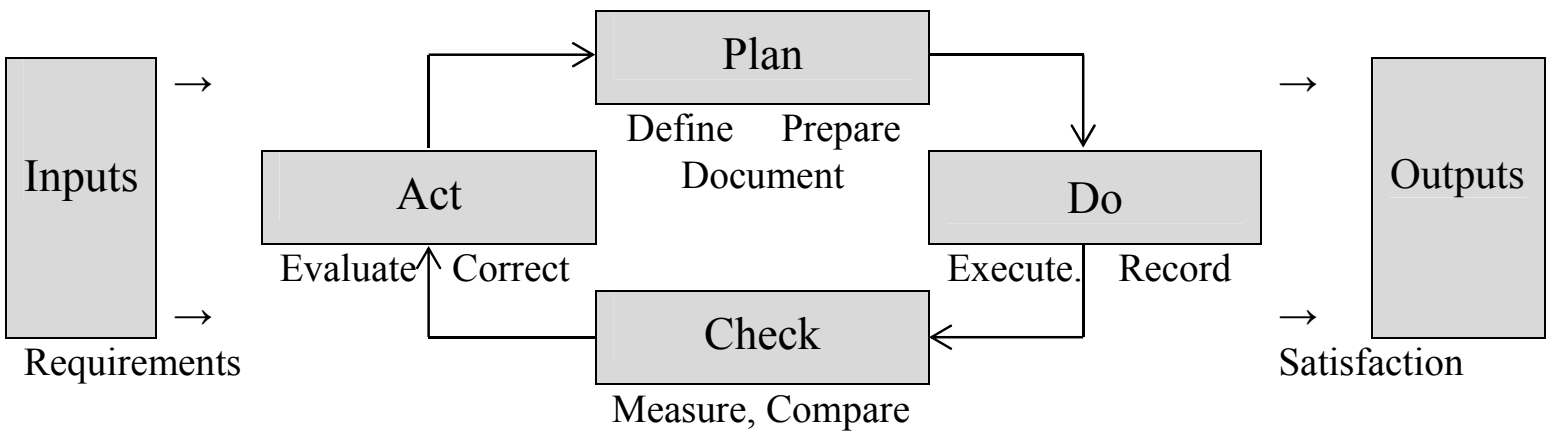

Fig. 1. Edward Deming PDCA Diagram

As mentioned earlier, productivity plays an essential role in any manufacturing systems and it normally depends on the product design, process design, namely the quality of equipment and facilities. The design of production processes includes the movements towards production design and this includes process design, establishment of facility location, devices layout, required capacities, process plans, production timing, supervision and control methods. Controls of manufacturing activities include operational and financial control. Control information is planned to make sure that it complies with operational activities with planned level to help decision making for development plans. Although, the initial design of the product $\&$ process have the greatest effect on productivity, it is required to control the operation and improve it continually (Prokopenko, 1992).

\subsection{Quality Management System}

Quality management system (QMS) can be expressed as the organizational structure, procedures, processes and resources required to implement quality management. Early systems concentrated on the outcomes of an industrial product production line, using simple statistics and random sampling. By the 20th century, labor inputs were typically the most costly inputs in most industrialized societies, so the focus was shifted to team cooperation and dynamics, especially the early development of problems via continuous improvement cycles. According to Pfeifer (2004) the necessary characteristics of QMS are summarized in Table 2. 
Table 2

Characteristic of QMS (Pfeifer,2004)

\begin{tabular}{ll}
\hline Characters & Definition \\
\hline Objective & Customer satisfaction through high quality products \\
Strategy & Arranging business processes according to requirements of standards \\
Management & Listing of management responsibilities \\
Organization & Process owner; management representative (responsible for QMS) \\
Regarded resources & Human resources, infrastructure and work environment \\
Training & Required, but not specified \\
Project Management & PDCA (model for continuous improvement, voluntary) \\
Process approach & Model of a process-based QMS No specification \\
Documentation & Listing of requirements \\
\hline
\end{tabular}

The ISO 9000 family of standards, published originally in 1987, was revised in 1994 and last time in December 2000. The revised ISO $9000: 2000$ is based on eight quality management principles (Topferand Gunther, 2003; Dey, 2002). The success of quality management plans requires the determination of the advantages of the performance of the plans. The barriers are dedicated to three general fields. If the measurements are reduced and elimination of the barriers is not performed within the organization, applying and keeping quality management system is getting difficult and sometimes it is impossible. It is often difficult to define the quality barriers and quality limitations in five fields are categorized as follows, (Hawaks et al., 1996). Fig 2. shows the main process of QMS.

- The support of management of quality

- The relation between the staffs and managers

- Communications

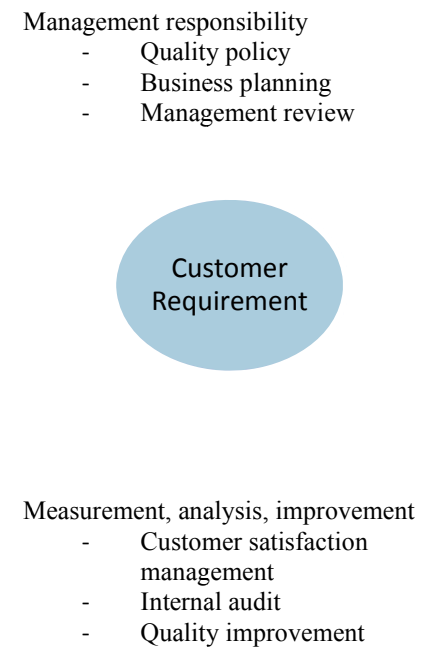

\section{Research Methodology}

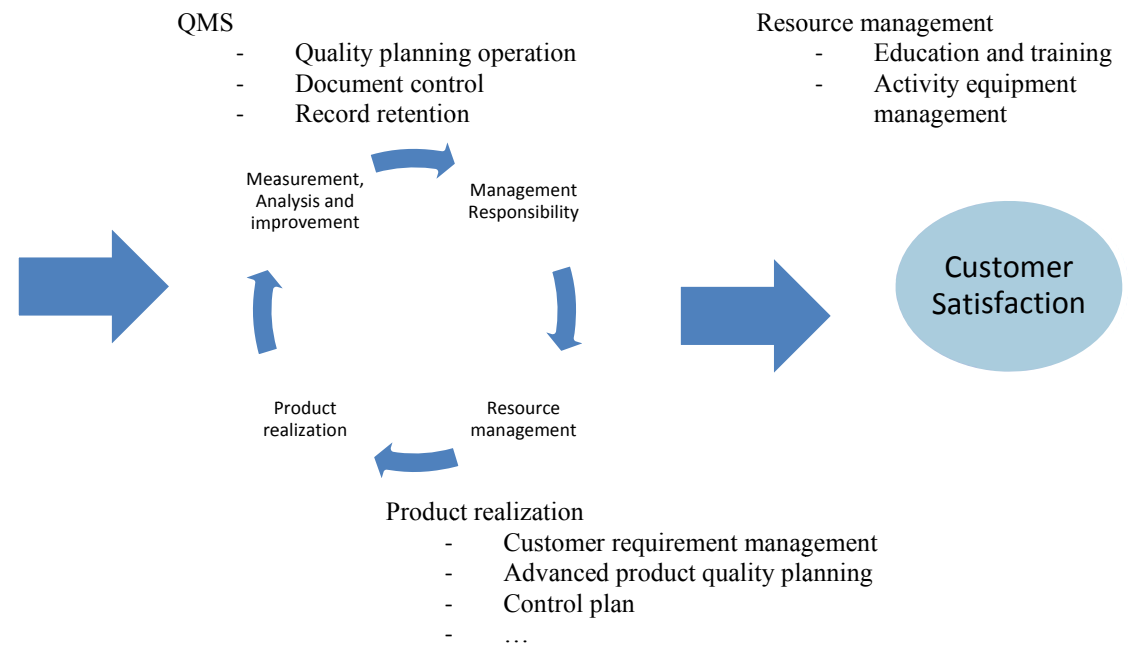

Fig. 2. Process of QMS
- Being the victim of the changes

- Management isolation

The present study has been surveyed in an Iranian firm called Aria Sanaat manufacturing company. There were 60 employees working for this firm and we selected 56 people as the sample according to expert's consideration and commands and simple random sampling. In this research, the relevant documentations have been surveyed to review the implementation steps by expert confirmation and the questionnaire have been used in order to check the hypotheses researches. Cronbach Alpha coefficient has been evaluated as $87.62 \%$ and experts confirmed the content of the questionnaire. Several factors can be mentioned due to the impact of efficiency in organizations. The present research has chosen and reviewed three key and important variables including "role of top organization management for QMS implementation", "Change management solutions implementation to eliminate organization resistance" and "fourteen Deming principles \& 
Organization Productivity". Fig. 3 shows the research conceptual model and different variables have been defined to implement statistical test. Full specifications of these variables can be seen in Appendix.

\begin{tabular}{|l|}
\hline Top management plays important role on QMS implementation \\
\hline Change management implementation reduces barriers for QMS \\
implementation
\end{tabular}

Fig. 3. Conceptual Model

Table 3 shows details of all six hypotheses as follows,

Table 3

Research Hypotheses

\begin{tabular}{cl}
\hline Hypotheses & \multicolumn{1}{c}{ Definition } \\
\hline First & $\begin{array}{l}\mathrm{H}_{0}: \text { Some of the organizations by spending adequate human resources and financial facilities can } \\
\text { continually perform quality management system. }\end{array}$ \\
Second & $\begin{array}{l}\mathrm{H}_{0}: \text { The commitment of top managers of the organizations whose products are with good quality is not } \\
\text { than the top managers of the organizations producing the low quality products. }\end{array}$ \\
Third & $\begin{array}{l}\mathrm{H}_{0}: \text { By applying change management principles, we cannot reduce the barriers in performing quality } \\
\text { management system or eliminate it. }\end{array}$ \\
Fourth & $\begin{array}{l}\mathrm{H}_{0}: \text { We cannot increase productivity considerably in the organization by applying Deming } 14 \text { points in } \\
\text { the main and current processes. }\end{array}$ \\
Sixth & $\begin{array}{l}\mathrm{H}_{0}: \text { By performing quality management system at organization, continually, we cannot increase the } \\
\text { organization productivity. }\end{array}$ \\
\hline
\end{tabular}

The distributions of the variables of hypotheses 1 to 6 are investigated as descriptively from very high, low, variance and responses mean.

\section{Table 4}

The descriptive investigation of the variables

\begin{tabular}{lcccc}
\hline Index & Responses & Low limit of the responses & Variance & Mean \\
\hline First hypothesis & 5 & 1 & 0.28 & 4.02 \\
Second hypothesis & 5 & 1 & 0.44 & 3.3 \\
Third hypothesis & 5 & 1 & 0.27 & 3.36 \\
Fourth hypothesis & 5 & 1 & 0.14 & 3.38 \\
Fifth hypothesis & 5 & 2 & 0.32 & 3.7 \\
Sixth hypothesis & 5 & 1 & 0.38 & 3.58 \\
\hline
\end{tabular}

As shown in Table 4, the highest mean is associated with the first hypothesis (4.02) and the lowest mean is associated with the second hypothesis (3.3).

\section{The results}

The proposed study of this paper uses t-student test to examine each hypothesis and Friedman test is applied to rank the relative importance of each hypothesis.

\subsection{The first hypothesis: The effect of human and financial resources}

The first hypothesis of this survey investigates the effects of human and financial resources on QMS. Table 5 demonstrates the results of our survey using one-sample test. 


\section{Table 5}

The results of testing the first hypothesis (Test value $=3$ )

\begin{tabular}{lcccccc}
\hline & & & & & \multicolumn{2}{c}{$95 \%$ confidence interval of the difference } \\
& $\mathrm{t}$ & $\mathrm{df}$ & Sig. (20tailed) & Mean difference & Lower & Upper \\
\hline VAR00001 & 11.783 & 55 & 0.000 & 1.0179 & 0.8447 & 1.1910 \\
VAR00002 & 8.423 & 55 & 0.000 & 1.0179 & 0.7757 & 1.2600 \\
F1 & 14.356 & 55 & 0.000 & 1.0179 & 0.8758 & 1.1699 \\
\hline
\end{tabular}

Based on the results of t-student is equal to 14.356, which is well above the critical value of 1.671 and we can reject the null hypothesis and conclude that the human and financial factors play important role on QMS implementation when the level of significance is five percent.

\subsection{The second hypothesis: The effect of top management commitment}

The second hypothesis of this survey investigates the effects of top management commitment on QMS. Table 6 demonstrates the results of our survey using one-sample test.

\section{Table 6}

The results of testing the second hypothesis (Test value $=3$ )

\begin{tabular}{lcccccc}
\hline & & & & & \multicolumn{2}{c}{$95 \%$ confidence interval of the difference } \\
& $\mathrm{t}$ & df & Sig. (20tailed) & Mean difference & Lower & Upper \\
\hline VAR00003 & 3.357 & 55 & 0.001 & 0.3571 & 0.1439 & 0.5703 \\
VAR00004 & 2.362 & 55 & 0.022 & 0.2500 & 0.0379 & 0.4621 \\
F2 & 3.415 & 55 & 0.001 & 0.3036 & 0.1254 & 0.4817 \\
\hline
\end{tabular}

Based on the results of t-student is equal to 3.415, which is well above the critical value of 1.671 and we can reject the null hypothesis and conclude that top management commitment plays important role on QMS implementation when the level of significance is five percent.

\subsection{The third hypothesis: The effect of change management on QMS implementation}

The third hypothesis of this survey studies the impacts of top management commitment on QMS. Table 7 shows the results of our survey using one-sample test.

\section{Table 7}

The results of testing the third hypothesis (Test value $=3$ )

\begin{tabular}{lcccccc}
\hline & & & & & \multicolumn{3}{c}{ 95\% confidence interval of the difference } \\
& $\mathrm{t}$ & $\mathrm{df}$ & Sig. (20tailed) & Mean difference & Lower & Upper \\
\hline VAR00005 & 1.030 & 55 & 0.308 & 0.1071 & -0.1014 & 0.3157 \\
VAR00006 & 4.529 & 55 & 0.001 & 0.6071 & 0.3385 & 0.8758 \\
VAR00007 & 3.357 & 55 & 0.000 & 0.3571 & 0.1439 & 0.5703 \\
F3 & 5.104 & 55 & 0.001 & 0.3571 & 0.2169 & 0.4974 \\
\hline
\end{tabular}

Based on the results of t-student is equal to 5.104, which is well above the critical value of 1.671 and we can reject the null hypothesis and conclude that change management plays essential role on QMS implementation when the level of significance is five percent.

\subsection{The fourth hypothesis: The effect of Deming 14 factors on QMS implementation}

The fourth hypothesis of this survey takes into consideration of the effects of Deming 14 factors on QMS. Table 8 demonstrates the results of our survey using one-sample test. Based on the results of tstudent is equal to 7.510, which is well above the critical value of 1.671 and we can reject the null hypothesis and conclude that Deming's 14 rules and regulations play important role on QMS implementation when the level of significance is five percent. 
Table 8

The results of testing the fourth hypothesis (Test value $=3$ )

\begin{tabular}{lcccccc}
\hline & & & & \multicolumn{3}{c}{$95 \%$ confidence interval of the difference } \\
& $\mathrm{T}$ & $\mathrm{df}$ & Sig. (20tailed) & Mean difference & Lower & Upper \\
\hline VAR00008 & 0.778 & 55 & 0.440 & 0.08929 & -0.1407 & 0.3192 \\
VAR00009 & 5.212 & 55 & 0.000 & 0.6429 & 0.3957 & 0.8900 \\
VAR00010 & 1.694 & 55 & 0.096 & 0.1786 & -0.0326 & 0.3898 \\
VAR00011 & -0.131 & 55 & 0.896 & -0.0179 & -0.2904 & 0.2547 \\
VAR00012 & 3.305 & 55 & 0.002 & 0.4107 & 0.1617 & 0.6597 \\
VAR00013 & 6.043 & 55 & 0.000 & 0.6429 & 0.4297 & 0.8561 \\
VAR00014 & 8.190 & 55 & 0.000 & 0.7143 & 0.5395 & 0.8891 \\
F4 & 7.510 & 55 & 0.000 & 0.3801 & 0.2787 & 0.4815 \\
\hline
\end{tabular}

\subsection{The fifth hypothesis: The effect of QMS on increasing productivity}

The fifth hypothesis of this survey studies the impacts of QMS on productivity improvement. Table 9 demonstrates the results of our survey using one-sample test.

\section{Table 9}

The results of testing the fifth hypothesis (Test value $=3$ )

\begin{tabular}{lcccccc}
\hline & & & & & \multicolumn{2}{c}{ 95\% confidence interval of the difference } \\
& $\mathrm{t}$ & $\mathrm{df}$ & Sig. (20tailed) & Mean difference & Lower & Upper \\
\hline VAR000014 & 6.130 & 55 & 0.000 & 0.5179 & 0.3486 & 0.6872 \\
VAR000015 & 7.865 & 55 & 0.000 & 0.8750 & 0.6520 & 1.0980 \\
F5 & 9.151 & 55 & 0.000 & 0.6964 & 0.5439 & 0.8489 \\
\hline
\end{tabular}

Based on the results of t-student is equal to 9.151, which is well above the critical value of 1.671 and we can reject the null hypothesis and conclude that QMS could improve productivity when the level of significance is five percent.

\subsection{The sixth hypothesis: The effect of educational factors on reducing barriers}

The last hypothesis of this survey studies of the impact of educational factors on reducing barriers. Table 10 summarizes the results of our survey using one-sample test.

\section{Table 10}

The results of testing the fourth hypothesis (Test value $=3$ )

\begin{tabular}{lcccccc}
\hline & & & & & & \\
& $\mathrm{T}$ & df & Sig. (20tailed) & Mean difference & Lower & Upper \\
\hline VAR00017 & 2.954 & 55 & 0.005 & 0.4107 & 0.1320 & 0.6894 \\
VAR00018 & 3.258 & 55 & 0.002 & 0.4464 & 0.1718 & 0.7211 \\
VAR00019 & 12.775 & 55 & 0.000 & 1.1786 & 0.9937 & 1.3635 \\
VAR00020 & 2.211 & 55 & 0.031 & 0.2857 & 0.0267 & 0.5447 \\
F4 & 7.090 & 55 & 0.000 & 0.5804 & 0.4163 & 0.7444 \\
\hline
\end{tabular}

Based on the results of t-student is equal to 7.090, which is well above the critical value of 1.671 and we can reject the null hypothesis and conclude that having educational programs among employees could reduce barriers on implementing QMS when the level of significance is five percent.

As we can observe, all six hypotheses of this survey have been confirmed bringing us to conclude that QMS implementation could improve the quality of final product. However, we need to find the relative importance of each hypothesis using Freedman test where the results are summarized in Table 11 as follows, 
Table 11

The results of Friedman test

\begin{tabular}{|c|c|c|c|c|c|c|c|c|}
\hline $\mathrm{H}$ & VAR & Mean Rank & $\mathrm{H}$ & VAR & Mean Rank & $\mathrm{H}$ & VAR & Mean Rank \\
\hline \multirow{2}{*}{1} & VAR1 & 1.46 & \multirow{7}{*}{4} & VAR8 & 3.44 & 5 & VAR15 & 1.38 \\
\hline & VAR2 & 1.54 & & VAR9 & 4.45 & \multirow{6}{*}{6} & VAR16 & 1.62 \\
\hline \multirow{2}{*}{2} & VAR3 & 1.55 & & VAR10 & 3.55 & & VAR17 & 2.29 \\
\hline & VAR4 & 1.45 & & VAR11 & 3.23 & & VAR18 & 2.34 \\
\hline \multirow{3}{*}{3} & VAR5 & 1.79 & & VAR12 & 4.11 & & VAR19 & 3.24 \\
\hline & VAR6 & 2.21 & & VAR13 & 4.52 & & \multirow[t]{2}{*}{ VAR20 } & \multirow[t]{2}{*}{2.13} \\
\hline & VAR7 & 1.99 & & VAR14 & 4.71 & & & \\
\hline
\end{tabular}

\section{Conclusion}

In this paper, we have presented an empirical investigation on the effects of QMS implementation to increase organizational productivity through implementing change management. The proposed study of this paper has designed a questionnaire and distributed among some managers of an Iranian firm. The results of testing six hypotheses have indicated that the proposed model of this paper could contribute to productivity improvement.

\section{References}

Aggelogiannopoulos, D. R. O. S. I. N. O. S., Drosinos, E. H., \& Athanasopoulos, P. (2007). Implementation of a quality management system (QMS) according to the ISO 9000 family in a Greek small-sized winery: a case study. Food control, 18(9), 1077-1085.

Defeo, J. A., \& Juran, J. M. (2010). Juran's Quality Handbook: The Complete Guide to Performance Excellence 6/e. McGraw-Hill Professional.

Dey, P. (2002). How to complement ISO 9001: 2000 with Six Sigma. iSixSigma LLC, available at http://isixsigma. com/library/content/c020211a. asp.

Feng, J., Prajogo, D. I., Tan, K. C., \& Sohal, A. S. (2006). The impact of TQM practices on performance: A comparative study between Australian and Singaporean organizations. European Journal of Innovation Management, 9(3), 269-278.

Gollop, F. M. (1979). Accounting for intermediate input: The link between sectoral and aggregate measures of productivity growth. The Meaning and Interpretation of Productivity, 318-33.

Kemp, S. (2006). Quality management demystified. McGraw-Hill.

Kim, D. Y., Kumar, V., \& Kumar, U. (2012). Relationship between quality management practices and innovation. Journal of Operations Management, 30(4), 295-315.

Kurosawa, K. (1975). An aggregate index for the analysis of productivity and profitability. Omega, 3(2), 157-168.

Pfeifer, T. (2002). Quality management: Strategies, methods, techniques. Hanser, Munich and Vienna.

Pfeifer, T., Reissiger, W., \& Canales, C. (2004). Integrating six sigma with quality management systems. The TQM Magazine, 16(4), 241-249.

Pineda, A. (1990). A Multiple Case Study Research to Determine and respond to Management Information Need Using Total-Factor Productivity Measurement (TFPM). Virginia Polytechnic Institute and State University.

Priede, J. (2012). Implementation of Quality Management System ISO 9001 in the World and Its Strategic Necessity. Procedia-Social and Behavioral Sciences, 58, 1466-1475.

Prokopenko, J. (1987). Productivity management: A practical handbook. International Labour Organisation.

Saari, S. (2006). Productivity. Theory and Measurement in Business. In Espoo, Finland: European Productivity Conference. 
Sadikoglu, E., \& Zehir, C. (2010). Investigating the effects of innovation and employee performance on the relationship between total quality management practices and firm performance: An empirical study of Turkish firms. International Journal of Production Economics, 127(1), 13-26.

Worrell, E., Laitner, J. A., Ruth, M., \& Finman, H. (2003). Productivity benefits of industrial energy efficiency measures. Energy, 28(11), 1081-1098.

Töpfer, A., \& Günther, S. (2007). Six Sigma im Wirkungsverbund mit ISO 9000: 2000. Six Sigma, 335-351.

Zhang, D., Linderman, K., \& Schroeder, R. G. (2012). The moderating role of contextual factors on quality management practices. Journal of Operations Management, 30(1), 12-23.

\section{Appendix}

The presented issues in appendix relate to research variable definitions which are defined in statistical tables in VAR terms. Indeed the defined variables are questions of the questionnaire, which are being used by the researcher during his studies in order to survey the respondents' comments.

\begin{tabular}{|c|c|c|}
\hline \multirow{3}{*}{1} & $\begin{array}{c}\text { First } \\
\text { Hypothesis } \\
\end{array}$ & $\begin{array}{l}\text { Some organizations are not able to implement the quality management system properly and } \\
\text { continuously by using the adequate facilities and human and financial resources. }\end{array}$ \\
\hline & VAR1 & $\begin{array}{l}\text { Some organizations are not able to implement the quality management system properly and } \\
\text { continuously by using the adequate facilities and human and financial resources. }\end{array}$ \\
\hline & VAR2 & $\begin{array}{l}\text { In some organizations after quality management system implementation, no interesting } \\
\text { improvement will be created in product quality and services and whole organization efficiency } \\
\text { growth. }\end{array}$ \\
\hline \multirow[b]{3}{*}{2} & $\begin{array}{c}\text { Second } \\
\text { Hypothesis }\end{array}$ & $\begin{array}{l}\text { The commitment of senior organization managers, whose products have proper quality, is more than } \\
\text { the commitments of whose product have a lower quality. }\end{array}$ \\
\hline & VAR3 & How much do senior organization managers have effective role in product quality? \\
\hline & VAR4 & $\begin{array}{l}\text { Senior organization managers have an important effect in decreasing the resistance of different } \\
\text { programs and designs. }\end{array}$ \\
\hline \multirow{4}{*}{3} & $\begin{array}{c}\text { Third } \\
\text { Hypothesis }\end{array}$ & $\begin{array}{l}\text { By using the change management principles, the limitations of management system implementation } \\
\text { can be reduced or destroyed. }\end{array}$ \\
\hline & VAR5 & $\begin{array}{l}\text { The organization can reduce the resistance of the employees' implementation by considering the } \\
\text { facilities and rewards for them. }\end{array}$ \\
\hline & VAR6 & $\begin{array}{l}\text { Any alternation in organization (alternation in organizational structure, alternation in senior } \\
\text { managers, alternation in responsibilities, authority and etc.,) can transform the sense of job security. }\end{array}$ \\
\hline & VAR7 & $\begin{array}{l}\text { Using of force, threats, strict for implementation of new organizational plans can lead to Effective } \\
\text { and timely programs implementation. }\end{array}$ \\
\hline \multirow{8}{*}{4} & $\begin{array}{c}\text { Fourth } \\
\text { Hypothesis }\end{array}$ & $\begin{array}{l}\text { By using the Deming four principles in main and flowing organization processes, the efficiency can } \\
\text { be highly increased in organization level. }\end{array}$ \\
\hline & VAR8 & Fixed organization aims can increase the product quality and organization services. \\
\hline & VAR9 & $\begin{array}{l}\text { Evaluation and improvement of planning processes, manufacturing and services can increase the } \\
\text { quality of products and services. }\end{array}$ \\
\hline & VAR10 & $\begin{array}{l}\text { Elimination of unnecessary and unrealistic slogans and goals leads to quality improvement and } \\
\text { efficiency in organizations. }\end{array}$ \\
\hline & VAR11 & $\begin{array}{l}\text { By substituting new methods of production and services through traditional methods, the } \\
\text { organizational processes can be improved and product and service quality and efficiency can be } \\
\text { increased. }\end{array}$ \\
\hline & VAR12 & $\begin{array}{l}\text { Using the statistical methods and reporting in desired context can increase the product quality and } \\
\text { service. }\end{array}$ \\
\hline & VAR13 & $\begin{array}{l}\text { Avoiding the consideration of multiple and unclear objectives, respecting the equality and fairness } \\
\text { between different employees in organization can create an era for organization improvement. }\end{array}$ \\
\hline & VAR14 & Subordinates training by managers and supervisors leads to better performing. \\
\hline \multirow{3}{*}{5} & $\begin{array}{c}\text { Fifth } \\
\text { Hypothesis }\end{array}$ & $\begin{array}{l}\text { Organization efficiency can be improved by implementing the quality management system in } \\
\text { organization level (continuously). }\end{array}$ \\
\hline & VAR15 & $\begin{array}{l}\text { The use of qualitative tools of quality management system has been able to increase the productivity } \\
\text { in organization? (Leads to decrease the product, time and human energy losses, on time deliver and } \\
\text { etc.) }\end{array}$ \\
\hline & VAR16 & $\begin{array}{l}\text { The ongoing (gradual) qualitative tools (EFQM-QFD-5S-SPC-MSA,..) of sudden use leads to } \\
\text { increase productivity and quality effectively? }\end{array}$ \\
\hline
\end{tabular}


Sixth By establishing the training and justification courses for employees, the resistance of program and Hypothesis organizational design implementation can be reduced.

VAR17 Establishing training and explanation courses and meetings for different managers and employees can decrease the problems of program implementation and organizational resistance.

6 VAR18 Effective communication between organizational hierarchy and managers and employees reduces the problems in new plans.

VAR19 Using qualified, trained, skilled and expert employees in new plans lead to decrease operational problems.

VAR20 By eliminating the barriers between employees (and managers) and encouragement to solve problems as a group and removing the fear of new plans, operational problems can be reduces. 